\title{
The Effect of Plyometric Knee Tuck Jump and Barrier Hops Training on Explosive Muscle Explosion Futsal Player
}

\author{
Mathlaul Anwar, Sunarno Basuki, Tri Irianto \\ Department of Sport Education and Health \\ Lambung Mangkurat University \\ Banjarmasin, Indonesia \\ matlaul.anwar@yahoo.com
}

\begin{abstract}
The futsal players of SMAN 3 Banjarmasin have weak passing and shooting; therefore, the researchers argue that the futsal players of SMAN 3 Banjarmasin do not have good leg muscle explosive power. This study aims to determine the effect of Plyometric knee tuck jump and barrier hops exercises on the explosive power of the limb muscles of SMAN 3 Banjarmasin. The research method used is a quasiexperiment method with data collection techniques carried out through the initial test, providing treatment as many as $\mathbf{1 6}$ meetings and final tests. The population in this study were all futsal players of SMAN 3 Banjarmasin totalling 20 people. A total sample of 20 people with a sampling technique using total sampling or saturated samples. From the research data that has been analyzed and theoretical reviews, it can be concluded: There is an effect of plyometric knee tuck jump training and barrier hops on the explosive power of the limb muscles of futsal players of SMAN 3 Banjarmasin. The average results of the initial test were 184.35 and the final test was 203.7 .
\end{abstract}

Keywords: plyometric, knee tuck jump, barrier hops and leg muscle power explosion

\section{INTRODUCTION}

Futsal is a sport that is loved by all levels of society, especially men, ranging from children, adolescents and adults. Futsal is a team game that is popular now and has even become a national game in every country. Futsal sports are developing very rapidly throughout Indonesia from urban areas to remote areas. Futsal is a game sport like football, where the size of the goal and the field is small, and generally requires a large room to play the sport, each team totalling 5 people [1]. Although futsal and soccer have the same goal of putting the ball in the opponent's goal, futsal and football are different. The difference can be seen from the size of the smaller futsal court and the smaller number of players. To be able to play futsal well, a person is required to have good muscular strength and good basic playing skills.

Muscle strength is the driving force that must be trained so that athletes have a good physical condition to obtain maximum performance. Muscle strength is a very important component to improve overall physical condition [2]. Because strength is the driving force of physical activity and strength plays an important role in protecting athletes or people from injury, besides that strength athletes will be able to run fast, throw or kick further and efficiently, hit harder, so can also help strengthen joints the joints.

Physical condition is very important in every sport; athletes who train regularly will certainly have a good physical condition. The good physical condition will make it easier for someone to do sports skills. If the physical condition is good, there will be: increased ability of the circulatory system and the work of the heart, increased strength, endurance, and the ability of other physical conditions, improve exercise, faster recovery in organs after exercise, and rapid response from bodily organisms [3].

The observations of researchers during the Futsal Championship match between the High School Advanced Level held at the Upik Futsal Indoor Banjarmasin field in 2015 the SMAN 3 Banjarmasin players have not given the desired results, most of them do not too hard pass and shooting. This makes researchers think that the futsal players of SMAN 3 Banjarmasin do not have good explosive power. Researchers also observed that when they practised, the players still had a lot of mistakes in carrying out basic techniques, which often happened was mistakes when passing and shooting. Passing is still weak so that it makes it easier for opposing players to grab the ball, as well as a shooting that is not too hard so that the opponent's goalkeeper can always catch or dispel the ball.

A futsal player who has good strength and speed will have good muscle explosive power too. Weak kicks when passing and shooting are because the driving muscles for doing the kick are not strong yet. One of the exercises to produce a hard kick is by training the speed and strength of the foot swing. Combined speed and strength training will result in increased muscle explosive power. Strength is the ability of muscles to release maximum strength in a very short time [3]. Training to increase leg muscle power is very much needed by futsal players. Good leg muscle explosive ability will produce hard kicks and create goals. One form of exercise that can increase explosive power is plyometric training.

Plyometric training is a training process with the aim of increasing muscle power by combining isotonic and isometric exercises using dynamic loading. Plyometric training can also be interpreted as an exercise with the aim of combining speed and force movements to make a movement with explosions. Before muscle contraction, there is a sudden stretch wherein the muscle must reach maximum strength with a short amount of time. With regard to the leg muscle power explosive ability possessed by futsal players of SMAN 3 Banjarmasin, it has not shown good results. It is seen when the player does a hard passing and shooting.

Researchers also see that most of them have not been able to play futsal with the maximum ability so they rarely win. 
Skill is the ability to carry out movements appropriately, quickly, and harmoniously so it cannot be simplified anymore [4]. As a solution to the problem above, the player should practice a lot, repeating the movements that support technical movements by carrying out forms of training to increase explosive power as a support to improve basic techniques such as passing and shooting.

\section{Methodology}

In this study, the method chosen was the quasiexperiment method. The research procedure consisted of an initial test (pre-test), which is a standing broad jump test, which is one of the tests whose purpose is to measure a person's ability to power. This test is performed on all players before and after being given treatment, is a test to determine the initial ability of the study sample, then dividing the sample into 2 groups, each group is given one treatment in the form of plyometric exercises.

Treatment for the group I is knee tuck jump is a form of jump training that begins with standing and bending the knee joint. The position of the two arms hanging at the side of the body, the movement is done by swinging both arms up followed by vertical jump height. Whereas treatment for group II, namely barrier hops, is a form of jump training performed on hurdles or obstacles that are between $30-91 \mathrm{~cm}$ high, placed in line with a distance determined by ability.

Both treatments were carried out 16 meetings, 3 meetings each week and continued with the final test (posttest), namely standing broad jump test with the aim of finding out whether there is an effect of plyometric knee tuck jump training and barrier hops on the ability of leg muscle explosive power of futsal players of SMAN 3 Banjarmasin.

\section{RESULTS AND DISCUSSION}

That the coefficient of t-test for knee tuck jump training on the explosive power of the limb muscles of Futsal SMAN 3 Banjarmasin in 2016 was 7,338. Test the significance of the $\mathrm{t}$-test (t-test) is done by consulting the price of $\mathrm{t}$ arithmetic with $\mathrm{t}$ table. At $\alpha=5 \%$ with $(\mathrm{n} 1+\mathrm{n} 2)-2=18$, the value of $\mathrm{t}$ table is 1.73 . Because the price of $t$ arithmetic is greater than t table $(7,338>1.73)$, then an alternative hypothesis $(\mathrm{Ha})$ which can be pronounced "there is an effect of knee tuck jump training on the explosive power of the limb muscles of SMAN 3 Banjarmasin", was accepted.

That the coefficient of t-test on the leg muscle explosive power of futsal players of SMAN 3 Banjarmasin in 2016 was 9,023 . Test the significance of the t-test (t-test) is done by consulting the price of $\mathrm{t}$ arithmetic with $\mathrm{t}$ table. At $\alpha=5 \%$ with $(n 1+n 2)-2=18$, the value of t table is 1.73 . Because the price of $t$ arithmetic is greater than t table (9.023>1.73), it can be decided that the alternative hypothesis ( $\mathrm{Ha}$ ) which reads "there is an influence between the barrier hops exercise on the explosive power of the limb muscles of SMAN 3 Banjarmasin in 2016", was accepted.

Based on the results of the study showed that plyometric knee tuck jump training and barrier hops, both have an influence on the leg muscle explosive power of futsal players of SMAN 3 Banjarmasin Seeing the results of data processing in this study knee tuck jump and barrier hops exercises are very good in increasing test scores if during the initial test the test scores are still low, although cumulatively barrier hops exercises are better than knee tuck jump exercises in improving test score results.

Physiologically the increase that occurs is due to an interaction between contractile proteins, namely actin and myosin in the muscles. Plyometric movements are believed to be based on the contraction of the muscle fibre reflexes as a result of the rapid loading of the same muscle fibres. The main sensory receptors are responsible for muscle spindles, which are able to respond to the magnitude and speed of change in the length of muscle fibres. Another type of stretching response, the Golgi tendon organ, is located within the tendons and responds to excessive tension as a result of strong contractions or muscle stretches [5].

The plyometric knee tuck jump and barrier hops training model can be used as a training model to increase leg muscle explosive power. Plyometric knee tuck jump and barrier hops are a series of explosive jump movements that are fast and precise. Knee jump training starts with the Quarter-Squad position, then jumps up quickly and repeatedly. This activity is a combination of eccentric contractions that are followed immediately by concentric contractions of skeletal muscles. The mechanism of knee tuck jump training emphasizes that maximum height affects muscle strength which results in agility and speed.

Barrier hops are performed by jumping over obstacles with two legs strong and fast. In this movement, the eccentric movement occurs when the muscles begin to elongate and the muscles are given a sudden load and are forced to stretch before concentric contractions occur and produce movements that move from one place to another, from which the movement will cause continuous muscle contractions. To practice hops, each player must jump over the goal that is given a distance of one meter from the next goal. The height of the goal that will be jumped over is the result of the calculation of the average length of the lower leg muscles of all players in the barrier hops group that has been reduced by $5 \%$ with the consideration that players who have shorter lower leg sizes do not have too much weight when jumping.

The exercise of knee tuck jump and barrier hops is done 16 times, which are held 3 times a week every Tuesday, Thursday, and Saturday. Every child has their own dose according to the basis of the maximum test and exercise program - the role of individual principles that distinguish the number of reps when each player does training. Players who have lower maximum test scores are certainly different from players who have high maximum tests. Training starts from 5 sets to the highest of 9 sets, with an intensity of 30$60 \%$. For resistance training that will focus on increasing explosive power, a form of jump squat training is an example of this type of exercise athletes use a load of around $30 \%$ $60 \%$ of 1 RM [6].

The height of the goal that is skipped over the barrier hops is $44 \mathrm{~cm} .44 \mathrm{~cm}$ is the average result of lower leg length of the barrier hops training group that has been reduced by $5 \%$, with the consideration that players who have a leg length below the average will not be too heavy to make the jump. Goal height refers to barrier hops are exercises that are carried out on goalposts or obstacles that are high (between 30-91 
this is in accordance with research conducted by Agung in 2013 the effect of Knee Tuck Jump Exercise on the Exploding Power of the Player's Leg Muscles. He concluded that Pliometric Knee Tuck Jump and Barrier Hops exercises are exercises that can improve the results of long-distance kicks on SSB Putra Men players .

Plyometric knee tuck jump and barrier hops have been shown to increase leg muscle explosive power. The increase in the ability of this explosive power certainly also affects the increase in power in passing and shooting in futsal. A futsal player who has good leg muscle explosive ability will produce a hard kick. The ability to make passing and shooting kicks in futsal is a hard demand to be able to create goals to win every game.

\section{CONCLUSION}

Based on the results of research and discussion in this thesis, it can be concluded that "There is an effect of plyometric knee tuck jump training and barrier hops on the explosive power of the limb muscles of futsal players.

\section{ACKNOWLEDGMENT}

We would like to be grateful to the Dean of Teacher Training and Education Faculty, Lambung Mangkurat University, who has supported us in the form of funding. Therefore we could join this International Conference.

\section{REFERENCES}

[1] S. Agung, Pengaruh Latihan Pliometric Knee Tuck Jump dan Barrier Hops terhadap Hasil Tendangan Jarak Jauh pada Pemain SSB Putra Laksana, Universitas Negeri Semarang, 2013.

[2] Harsono, Coaching dan Aspek-aspek Psikologis dalam Coaching, Jakarta: Departemen Pendidikan dan Kebudayaan, 1988.

[3] T. Bompa, Periodization Training For Sports. Human Kinetics, 1999.

[4] A.S. Hanif, Evaluasi Terhadap Sekolah Khusus Olahragawan SMP/SMA, Jakarta, 2011

[5] J.C. Radcliffe, and R.C. Farentinos, Plyometrics: Explosive Power Training., Illinois: Human Kinetics Publisher. Inc, 1985.

[6] D.A. Chu, and G.D. Myer, Gregory. D. 2013. Plyometrics. Champaign, Illinois: Human Kinetics Pub.

[7] E.L. Fox, R.W. Bower, and M.L. Fose, The Physiological Basis of Physical Education an Atletic, New York: Sounder College Publishing, 1988.

[8] J. Lubis, Panduan Praktis Penyusunan Program Latihan, Jakarta: PT. Rajagrafindo Persada, 2013. hamstring, and gastrocnemius muscles that move simultaneously with isometric and isotonic motion [8]. The form of plyometric knee tuck jump training and barrier hops is very well used to increase leg muscle explosive power, and 